\title{
Health and economic outcomes associated with uncontrolled surgical bleeding: a retrospective analysis of the Premier Perspectives Database
}

This article was published in the following Dove Press journal:

ClinicoEconomics and Outcomes Research

22 July 2015

Number of times this article has been viewed

\section{Mitra Corral' \\ Nicole Ferko² \\ Sarah Hollmann ${ }^{2}$ \\ Michael S Broder ${ }^{3}$ \\ Eunice Chang ${ }^{3}$}

'Ethicon Biosurgery, Somerville, NJ, USA; ${ }^{2}$ Cornerstone Research Group, Burlington, ON, Canada; ${ }^{3}$ Partnership for Health Analytic Research, Beverly Hills, CA, USA
Correspondence: Nicole Ferko Cornerstone Research Group, Suite 204, 3228 South Service Road, Burlington, ON L7N3H8, Canada

Tel + I 905637623 I (ext 236)

Fax + I 9056375014

Email nferko@cornerstone-research.com
Background: Bleeding remains a common occurrence in surgery. Data describing the burden of difficult-to-control bleeding and topical absorbable hemostat use are sparse. This study was conducted to estimate the clinical and economic impact that remains associated with uncontrolled surgical bleeding, even when hemostats are used during surgery.

Methods: This US retrospective analysis used the Premier Perspectives Database. Hospital discharges from 2012 were used to identify patients treated with hemostats during eight surgery types. Patients were included if they were $\geq 18$ years, had an inpatient hospitalization with one of the eight surgeries, and received a hemostat on the day of surgery. Patients were stratified by procedure and presence or absence of major bleeding (uncontrolled) despite hemostat use. Outcomes were all-cause hospitalization costs, hemostat costs, length of stay, reoperation, and surgery-related complications (eg, mortality). Statistical significance was tested through chi-square or $t$-tests. Multivariate analyses were conducted for all-cause costs and length of stay using analysis of covariance.

Results: Among 25,048 procedures, major bleeding events occurred in 14,251 cases. Despite treatment with hemostats, major bleeding occurred in $32 \%-68 \%$ of cases. All-cause costs were significantly higher in patients with uncontrolled bleeding despite hemostat use versus controlled bleeding (US\$24,203-\$61,323 [uncontrolled], US\$14,420-\$45,593 [controlled]; $P<0.001)$. Hemostat costs were significantly greater in the uncontrolled bleeding cohort for all surgery types except cystectomy and pancreatic surgery. Reoperation and mortality rates were significantly higher in the uncontrolled bleeding cohort in all surgical procedures except cystectomy and radical hysterectomy.

Conclusion: Uncontrolled intraoperative bleeding despite hemostat use is prevalent and associated with significantly higher hospital costs and worse clinical outcomes across several surgical procedures compared to controlled bleeding. There is an unmet need for newer hemostats that can more effectively control bleeding, improve outcomes, and reduce hospital resource use.

Keywords: hemostat, costs, bleeding, Premier, surgery, burden

\section{Background}

Intraoperative and postoperative bleeding remains a common major complication of surgery. ${ }^{1-5}$ An aging population with growing comorbidities and high anticoagulant use are important factors that contribute to high surgical bleeding risks. ${ }^{6-8}$ Surgical bleeding can range from mild or moderate in intensity to severe or traumatic. There are a number of conventional surgical methods (eg, suture, ligature, compression, and cautery) and topical absorbable hemostats (TAHs) available to achieve hemostasis in mild to moderate bleeding scenarios. ${ }^{9-13}$ Hemostatic agents in particular have become a growing treatment option over the past couple of decades, and have been associated with improved surgical and clinical outcomes. ${ }^{14}$ 
Mild or moderate surgical bleeding may be straightforward to manage; however, bleeding may also be problematic or difficult to control, depending on several factors including bleeding severity, visibility and access to the bleeding source, anatomic location of the bleeding, patient coagulation status, and surgical skill. ${ }^{12}$ These types of bleeding scenarios are often referred to in the literature using several common bleeding terms including severe, ${ }^{1}$ major, ${ }^{5}$ or excessive. ${ }^{15}$ For example, diffuse bleeding from broad surface areas in patients who are coagulopathic may be particularly difficult to manage which may lead to additional procedures such as blood transfusion. ${ }^{9}, 12$ Traumatic bleeding may be placed at the top of this spectrum where patients have severe bleeding from injured tissues and often traditional methods of hemostasis are ineffective, necessitating multiple units of transfused blood. ${ }^{16,17}$

In more problematic and difficult bleeding, there is often no single solution that can allow surgeons to rapidly stop bleeding. ${ }^{18-20}$ As a result, these situations often involve combinational use of hemostatic products in addition to conventional methods, which may be cumbersome, time-consuming, and costly. ${ }^{12,21}$ Furthermore, several studies describe the substantial clinical and economic burden with such bleeding. ${ }^{15,16,22-24}$ Bleeding can lengthen, interrupt, or complicate the surgery as well as increase likelihood of transfusion, reoperation, and associated complications. ${ }^{22,25-28}$ Furthermore, it has been reported that severe, excessive, or uncontrolled bleeding during surgery can increase mortality rates to $20 \% .{ }^{1,3}$ It has also been estimated that uncontrollable bleeding accounts for approximately $40 \%$ of trauma-related deaths. $^{29}$

Despite available data describing the burden of difficult or uncontrollable bleeding, there is still a need to understand how hemostat use impacts the incidence of such bleeding, and the risk of associated complications. Currently, no studies have explicitly assessed the burden of surgical bleeding in relation to hemostat use. Consequently, this retrospective analysis of the Premier database was conducted to estimate the hospital resources and costs that remain associated with uncontrolled surgical bleeding, even when hemostatic agents are used during surgery.

\section{Methods}

\section{Study design and data source}

A retrospective analysis was conducted using data from the Premier Perspectives Database (PPD). Information contained within the PPD is de-identified making it fully compliant with the Health Insurance Portability and
Accountability Act (HIPAA). The PPD includes data on more than 600 participating hospitals and 47 million hospital discharges in the US. Participating hospitals submit data on patient demographic and payer information as captured on the hospital billing record. Before the information is added to the database, all data go through quality assurance and validation checks. Available data include all billed items by the cost-accounting department, including medications; laboratory, diagnostic, and therapeutic services; and primary and secondary diagnoses for each patient. Further, hospital information, such as geographical location, bed size, and teaching hospital status, is also included within the PPD.

\section{Patient population}

All hospital discharges with admission dates in 2012 were used to identify patients who were treated with hemostatic agents during select surgeries. Eight major surgeries were selected that were deemed by surgeons to be commonly associated with major bleeding and included cardiac revascularization, cardiac valve surgery, cholecystectomy, cystectomy, pancreatic, partial hepatic resection, pulmonary, and radical abdominal hysterectomy. Surgeries of interest were identified using the International Classification of Diseases, 9th Revision, Clinical Modification (ICD-9-CM) procedure codes (Table S1). Specific hemostatic agents used in surgery included mechanical, thrombin, flowable, and fibrin sealant agents (Table S2). Patients were identified for inclusion if they were admitted to a hospital in 2012, underwent an inpatient surgery of interest as the primary procedure, and received a hemostatic agent on the day of the surgery. Patients were excluded if they were less than 18 years old or had received an additional major surgical procedure on a different body system on the same day as the index procedure. For patients with multiple hospitalizations, only the first was included for analysis.

\section{Major bleeding events}

Within each of the eight surgery subgroups, patients were further stratified by the presence or absence of a major bleeding (ie, uncontrolled bleeding) event despite hemostat use. Major bleeding events were identified by following the ICD-9-CM diagnosis and procedure codes: hemorrhage or hematoma complicating a procedure ( 998.11 and 998.12 ); interventions to control bleeding $(34.09,39.98,44.44,44.49,54.19,39.41$, $34.03,54.12,57.93)$; charges billed for use of hemovac drainage devices; charges billed for use of erythropoietin; blood product transfusions (99.00-99.09); and charges billed for cryoprecipitates, fresh frozen plasma, red blood cells, plasma, 
platelets, and whole blood. A detailed listing of these major bleeding events is outlined in Table S3.

\section{Study outcomes}

The main study outcomes included in the study were the all-cause costs incurred during hospitalization, the cost of hemostatic agents, length of stay (LOS) between surgery and discharge, intensive care unit (ICU) stay, operation time, reoperation, and potential surgery-related complications (eg, mortality, infection, transfusions, ventilator use). Total all-cause costs included room and board, surgery, professional fees, supplies, pharmacy services, and laboratory services. Reoperation was defined as procedures on the same body system as the original procedure, performed during the same hospitalization. Additionally, both infections and transfusions were defined according to specific ICD-9-CM codes, which are summarized in Tables S4 and S5, respectively. Other study measures included were patient demographics, payment source, admitting hospital characteristics, type of hemostatic agents used (eg, mechanical, active, flowable, fibrin sealant), and the all payer refined-diagnosis related groups (APR-DRGs). The APR-DRG simultaneously evaluates the interactions of multiple comorbidities, age, and primary and secondary discharge diagnoses.

\section{Statistical analyses}

All data transformations and statistical analyses were performed using $\mathrm{SAS}^{\circledR}$ version 9.4 (SAS Institute, Cary, NC, USA). Patient demographics and hospital characteristics were evaluated for all surgical subgroups combined. Descriptive statistics (eg, means, patient counts) were stratified by the presence or absence of major (ie, uncontrolled) bleeding events. All statistical analyses on outcome measures were conducted separately for each surgical subgroup. Chi-square or $t$-tests were used to test for statistical significance whenever applicable; all tests were two-sided with a significance level of 0.05 . Multivariate analyses were conducted to compare all-cause costs and LOS between patients with and without uncontrolled bleeding. Patient demographics and admitting hospital characteristics thought to have an impact on costs and LOS were included into the multivariate analysis, including age, race, sex, payment source, hospital geographic region, hospital location (rural vs urban), surgical admission type (elective vs emergent), teaching hospital status, and bed size. Analysis of covariance (ANCOVA) was used to adjust for these baseline characteristics.

\section{Results}

A total of 50,696 patients were identified within the Premier database that underwent a selected surgery in 2012, of which 25,155 were excluded because no hemostatic agent was used during surgery (Figure 1). Of the remaining 25,541 patients, 125 were excluded as they were younger than 18 years, and 368 were further excluded because they required additional surgery on a different body system on the same day. Thus, 25,048 patients were included in the analysis (cardiac revascularization: 12,799 ; cardiac valve surgery: 8,016 ; cholecystectomy: 1,576; cystectomy: 423 ; pancreatic: 464 ; partial hepatic: 620; pulmonary: 954; radical abdominal hysterectomy: 196).

Patient demographics and admitting hospital characteristics are presented in Tables 1 and 2. There were some notable differences between controlled and uncontrolled bleeding patients. In particular, there was a larger percentage of urgent cases in the uncontrolled versus controlled bleeding group (ie, $52 \%$ vs $40 \%$ ), as well as a higher proportion of extreme APR-DRG disease severity in uncontrolled versus controlled bleeding (ie, $28 \%$ vs $8.4 \%$ ).

Among 25,048 procedures, 14,251 uncontrolled bleeding events were recorded. The prevalence of uncontrolled bleeding events within each surgical subgroup is presented in Figure 2. Despite the use of hemostatic agents, uncontrolled bleeding events occurred in $32 \%-68 \%$ of patients, depending on the type of procedure. The most common type of event was use of a blood product, which occurred in $49.0 \%$ of all patients. Within the uncontrolled bleeding cohort, $25 \%-71 \%$ of patients required transfusions, with $5.8 \%-32.8 \%$ of patients receiving platelets, and up to $3.2 \%$ receiving coagulation factors. By definition, patients in the controlled bleeding cohort did not require transfusions.

Mortality for each surgical subgroup, stratified by the presence of uncontrolled bleeding despite hemostat use, is presented in Figure 3. Mortality was statistically significantly higher in the uncontrolled versus controlled bleeding cohort in all surgical subgroups except cystectomy and radical hysterectomy. Mortality rates ranged from $1.2 \%$ to $7.3 \%$ for uncontrolled bleeding and $0 \%$ to $1.2 \%$ for controlled bleeding cohorts.

Results pertaining to hospital resource use and costs are presented in Tables 3 and 4 for each surgical group, stratified by the presence or absence of uncontrolled bleeding despite hemostat use. All-cause costs were statistically significantly greater in patients with uncontrolled bleeding versus controlled bleeding for all surgery subgroups (uncontrolled bleeding: US\$24,203-\$61,323 vs controlled 


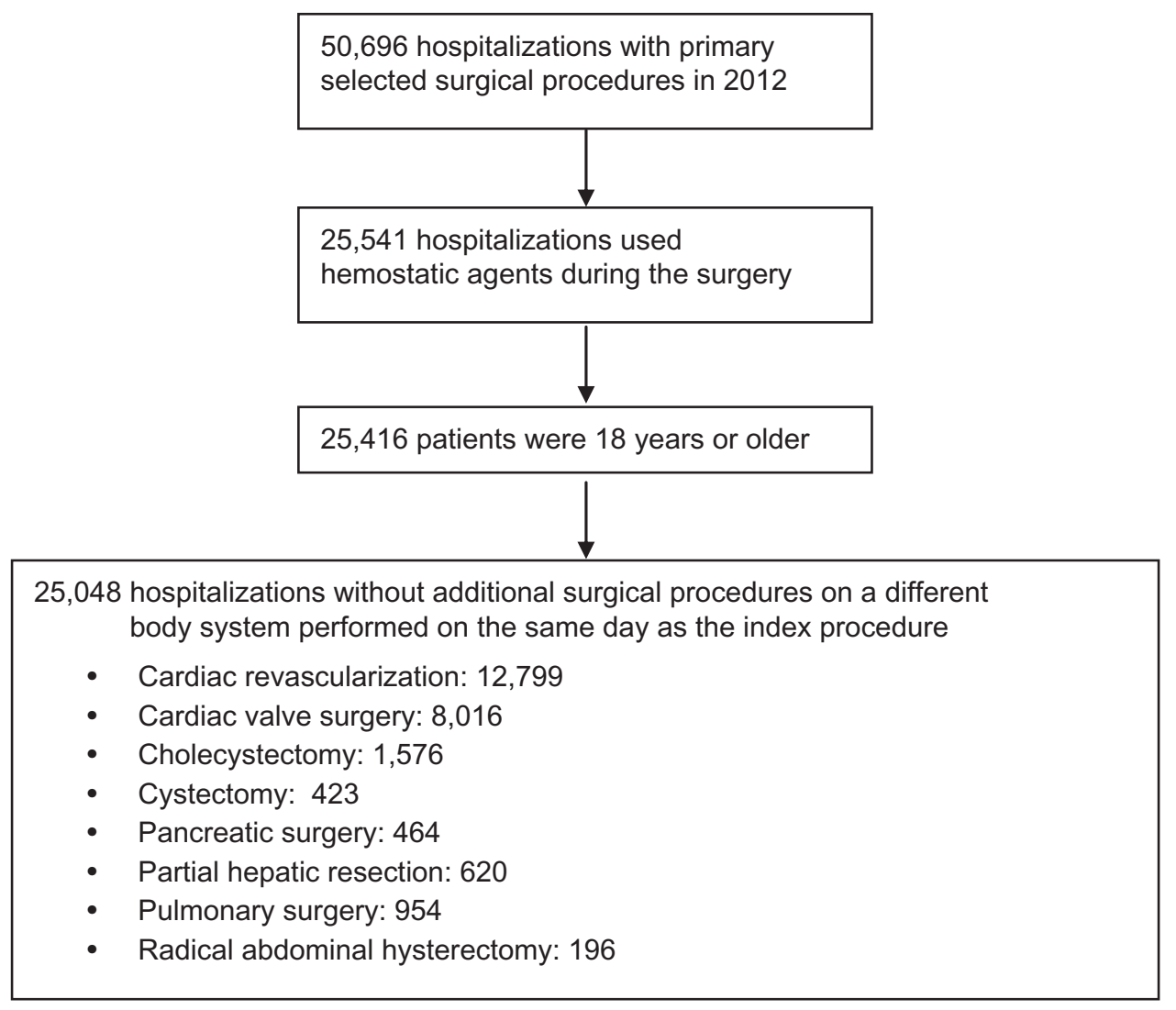

Figure I Patient identification flow chart.

bleeding: US\$14,420-\$45,593; $P<0.001)$. Similarly, LOS was also statistically significantly greater with uncontrolled bleeding patients for all subgroups (uncontrolled bleeding: 7.1-17 days vs controlled bleeding: 4.1-10 days; $P<0.001$ ). After adjusting for baseline differences, results for all-cause costs and LOS were consistent with unadjusted values (Table 4).

The cost of hemostatic agents was also statistically significantly greater in the uncontrolled bleeding cohort for all surgical groups, except pancreatic surgery and cystectomy (uncontrolled bleeding: US\$287-\$799 vs controlled bleeding: US\$203-\$451) (Table 3). Furthermore, ICU stay and infection were always statistically significantly greater in the uncontrolled versus controlled bleeding cohorts, across surgery subgroups. Reported infections included urinary tract infections, septicemia, fever, and pneumonia. Reoperation rates were also statistically significantly greater in uncontrolled bleeding patients, with the exception of radical abdominal hysterectomy. Ventilator use was also more common in uncontrolled bleeding in all surgery cohorts except cystectomy. Finally, operating time was typically higher in uncontrolled versus controlled bleeding cohorts by 13.3-37.6 minutes, but differences were only statistically significant for cardiac revascularization, cardiac valve surgery, pulmonary surgery, and radical hysterectomy (Table 3).

\section{Discussion}

Using a sample of over 25,000 patients, we found that a substantial proportion of patients have uncontrolled surgical bleeding despite current hemostat use, with rates ranging from $32 \%$ to $68 \%$ depending on the procedure. Both infection rate and mortality were statistically significantly higher for uncontrolled versus controlled bleeding cohorts for all surgery types. Resource use, including length of hospital stay, ICU stay, ventilator use, operation time, and reoperation were often higher in patients with uncontrolled bleeding. These results were consistent with adjusted all-cause costs, which were always significantly greater in uncontrolled versus controlled bleeding cohorts.

Several studies have reported on the risk of surgical bleeding; however, reported rates span a wide range, which may be due to varying definitions of bleeding, differences in study design and geographic location, as well as variations in surgical procedures studied. ${ }^{1,5,15,24}$ For example, a recent study by Dyke et $\mathrm{al}^{1}$ reported a major (ie, moderate or severe/massive) bleeding rate of $33.8 \%$ in cardiac surgery. Classification 
Table I Baseline patient demographics and admitting hospital characteristics

\begin{tabular}{|c|c|c|c|}
\hline I.I & $\begin{array}{l}\text { Bleeding not } \\
\text { controlled } \\
\text { despite } \\
\text { hemostat use } \\
(\mathrm{N}=\mid 4,25 \mathrm{I})\end{array}$ & $\begin{array}{l}\text { Bleeding } \\
\text { controlled } \\
\text { with hemostat } \\
(\mathrm{N}=10,797)\end{array}$ & $P$-value \\
\hline Age, mean (SD) & 67 (11.9) & $63.9(12.0)$ & $<0.001$ \\
\hline Female, N (\%) & $5,359(37.6)$ & $3,143(29.1)$ & $<0.001$ \\
\hline Race, N (\%) & & & $<0.001$ \\
\hline White & $|0,54|(74.0)$ & 7,983 (73.9) & \\
\hline Black & $\mathrm{I}, 085(7.6)$ & $702(6.5)$ & \\
\hline Other & $2,625(18.4)$ & $2,112(19.6)$ & \\
\hline Payment source, N (\%) & & & $<0.00 \mathrm{I}$ \\
\hline $\begin{array}{l}\text { Managed care/ } \\
\text { commercial }\end{array}$ & $3,373(23.7)$ & $3,642(33.7)$ & \\
\hline Medicare & 8,817 (61.9) & $5,517(5 I . I)$ & \\
\hline Other & $2,06 \mid(14.5)$ & $1,638(15.2)$ & \\
\hline Admission type, N (\%) & & & $<0.001$ \\
\hline Elective & $6,840(48.0)$ & 6,469 (59.9) & \\
\hline Urgent/emergent & $7,4 \mid I(52.0)$ & $4,328(40.1)$ & \\
\hline $\begin{array}{l}\text { Type of hemostatic } \\
\text { agent, } N(\%)\end{array}$ & & & $<0.001$ \\
\hline Active & $\mathrm{I}, 774(\mathrm{I} 2.4)$ & $\mathrm{I}, 604(\mathrm{I} 4.9)$ & \\
\hline Fibrin sealant & $2,287(16.0)$ & $\mathrm{I}, 40 \mathrm{I}(\mathrm{I} 3.0)$ & \\
\hline Mechanical & $5,295(37.2)$ & $5,057(46.8)$ & \\
\hline Multiple categories* & $4,895(34.3)$ & $2,735(25.3)$ & \\
\hline $\begin{array}{l}\text { APR-DRG disease } \\
\text { severity, } N(\%)\end{array}$ & & & $<0.001$ \\
\hline Minor & $593(4.2)$ & I,196 (II.I) & \\
\hline Moderate & $3,582(25.1)$ & $4,812(44.6)$ & \\
\hline Major & $6,040(42.4)$ & $3,884(36.0)$ & \\
\hline Extreme & $4,036(28.3)$ & $905(8.4)$ & \\
\hline
\end{tabular}

Note: *More than one hemostat used per patient.

Abbreviations: N, number of patients; SD, standard deviation; APR-DRG, all payer refined-diagnosis related groups.

Table 2 Hospital characteristics

\begin{tabular}{|c|c|c|c|}
\hline 1.2 & $\begin{array}{l}\text { Bleeding not } \\
\text { controlled despite } \\
\text { hemostat use } \\
(\mathrm{N}=\mid \mathbf{4 , 2 5} \mathrm{I})\end{array}$ & $\begin{array}{l}\text { Bleeding } \\
\text { controlled with } \\
\text { haemostat } \\
(\mathbf{N}=10,797)\end{array}$ & $P$-value \\
\hline $\begin{array}{l}\text { Hospital region } \\
\text { (US), N (\%) }\end{array}$ & & & $<0.001$ \\
\hline Northeast & 3,057 (21.5) & I,848 (I7.I) & \\
\hline Midwest & I,829 (I2.8) & $2,382(22.1)$ & \\
\hline West & 2,177 (I5.3) & $2,210(20.5)$ & \\
\hline South & $7,188(50.4)$ & $4,357(40.4)$ & \\
\hline $\begin{array}{l}\text { Teaching hospital, } \\
\mathrm{N}(\%)\end{array}$ & & & $<0.001$ \\
\hline Yes & 8,178 (57.4) & $5,488(50.8)$ & \\
\hline No & $6,073(42.6)$ & $5,309(49.2)$ & \\
\hline $\begin{array}{l}\text { Location of } \\
\text { hospital, N (\%) }\end{array}$ & & & $<0.001$ \\
\hline Rural & I, I76 (8.3) & I,206 (II.2) & \\
\hline Urban & I3,075 (9I.7) & 9,59। (88.8) & \\
\hline Bed size, N (\%) & & & $<0.001$ \\
\hline$<750$ & $10,903(76.5)$ & $9,428(87.3)$ & \\
\hline $750+$ & $3,348(23.5)$ & $1,369(12.7)$ & \\
\hline
\end{tabular}

Abbreviation: $\mathrm{N}$, number of patients. of major bleeding in this study depended on the amount of total blood loss, transfusion units, need for surgical re-exploration, and whether there was delayed sterna closure. This rate is reportedly lower than the observed rate of $56 \%-68 \%$ in cardiac revascularization or valve surgery in this study. Another study by Stone et $\mathrm{al}^{5}$ reported a major bleeding rate in the US cardiac surgery patients of $52.9 \%$ where the bleeding definition encompassed decrease in hemoglobin levels, reoperation for bleeding, access site hemorrhage requiring intervention, $\geq 5 \mathrm{~cm}$ hematoma, or transfusion. Other studies reported major or excessive bleeding rates of lower than $10 \%$; however, those studies used a more restrictive definition, which specified the number of transfusion units needed to qualify under the bleeding definition ${ }^{24}$ or the amount of postoperative bleeding drainage in cardiac surgery. ${ }^{15}$ Our study included more liberal definitions of uncontrolled bleeding as well as several additional surgery types relative to these latter studies. Also, our study included eight surgery types deemed by surgeons to be commonly associated with major bleeding. Furthermore, unlike our study which focused solely on surgeries involving hemostat use, it is unclear to what extent hemostats were used in most of these published studies reporting bleeding risk.

These current study findings are aligned with studies that have quantified resource use and costs associated with surgical bleeding. An earlier 2011 US study by Stokes et $\mathrm{al}^{23}$ reported that patients with bleeding-related complications (eg, transfusions) across different surgery types had significantly greater hospital costs and longer LOS. Our current study adds additional granularity in the types of resources comprising greater hospital costs in uncontrolled bleeding patients, such as reoperation, infection treatment, and ICU stay. Further, our study uniquely shows that these additional resources and costs are still high despite single or multiple hemostat product use. From the European perspective, Christensen et a ${ }^{15}$ demonstrated that hospital costs and resources including ICU stay, ventilator, and reoperation were significantly higher in patients with excessive postoperative bleeding compared to patients without.

The uptake of hemostats has been rapid over the last several years. A study by Wright et a ${ }^{14}$ showed that hemostat use continues to rise even for surgical procedures that are associated with very low bleeding complication and transfusion risk. Reviews of randomized trials demonstrate that hemostats can improve hemostasis and certain resource outcomes (eg, transfusions); however, benefits may vary by patient population type and hemostat product used. ${ }^{30-34}$ In surgical situations where bleeding is more difficult to 


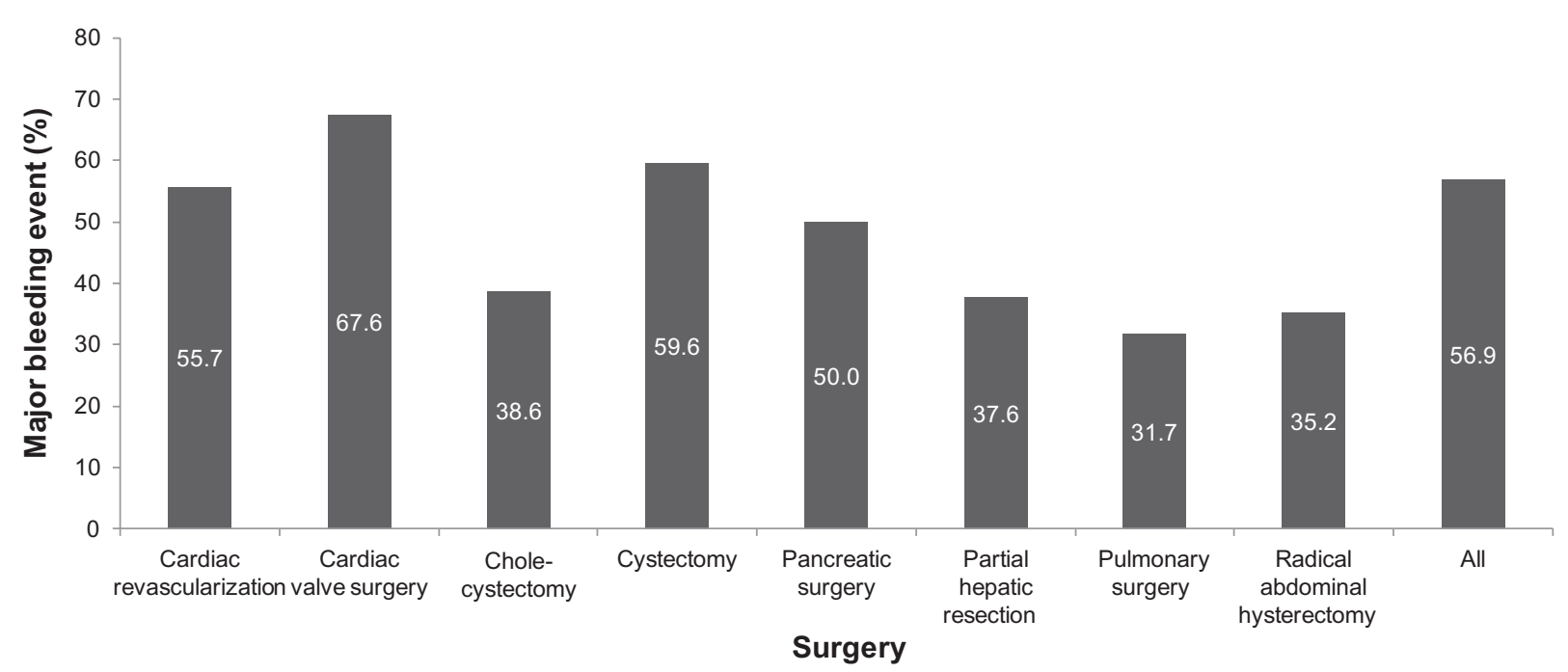

Figure 2 Percentage of patients with a major bleeding event despite hemostat use, stratified by surgery group.

Notes: Major bleeding (ie, uncontrolled bleeding) events were defined as: hemorrhage or hematoma complicating a procedure; interventions to control bleeding; charges billed for use of hemovac drainage devices; charges billed for use of erythropoietin; blood product transfusions; and charges billed for cryoprecipitates, fresh frozen plasma, red blood cells, plasma, platelets, and whole blood.

control, combined use of multiple hemostats is sometimes undertaken to try to achieve hemostasis. ${ }^{12,21}$ In our study, hemostat costs have been observed to be significantly higher in patients with uncontrolled bleeding, which may be partially explained by more combination hemostat use. Despite these additional hemostat costs, uncontrolled bleeding rates and associated resource use remained high, signifying the suboptimal benefit that some currently approved hemostats may have. Limitations with such hemostats, including insufficient adhesion strength, lack of efficacy in a wet field, and inability to withstand forces of brisk hemorrhage, may explain the continued risk of uncontrolled bleeding in many surgery types. ${ }^{9}, 12,18-20$

To address the prevalent problem of difficult-to-control surgical bleeding, a multifaceted approach is required. Essentially, methods to better assess appropriateness of operation technique and use of the various surgical methods for hemostasis are needed. Optimizing the use of right hemostatic technique (or product) with the right procedure can be an important goal for continuing education. Furthermore, new hemostats becoming available on the market that are targeted to problematic bleeding situations may help to

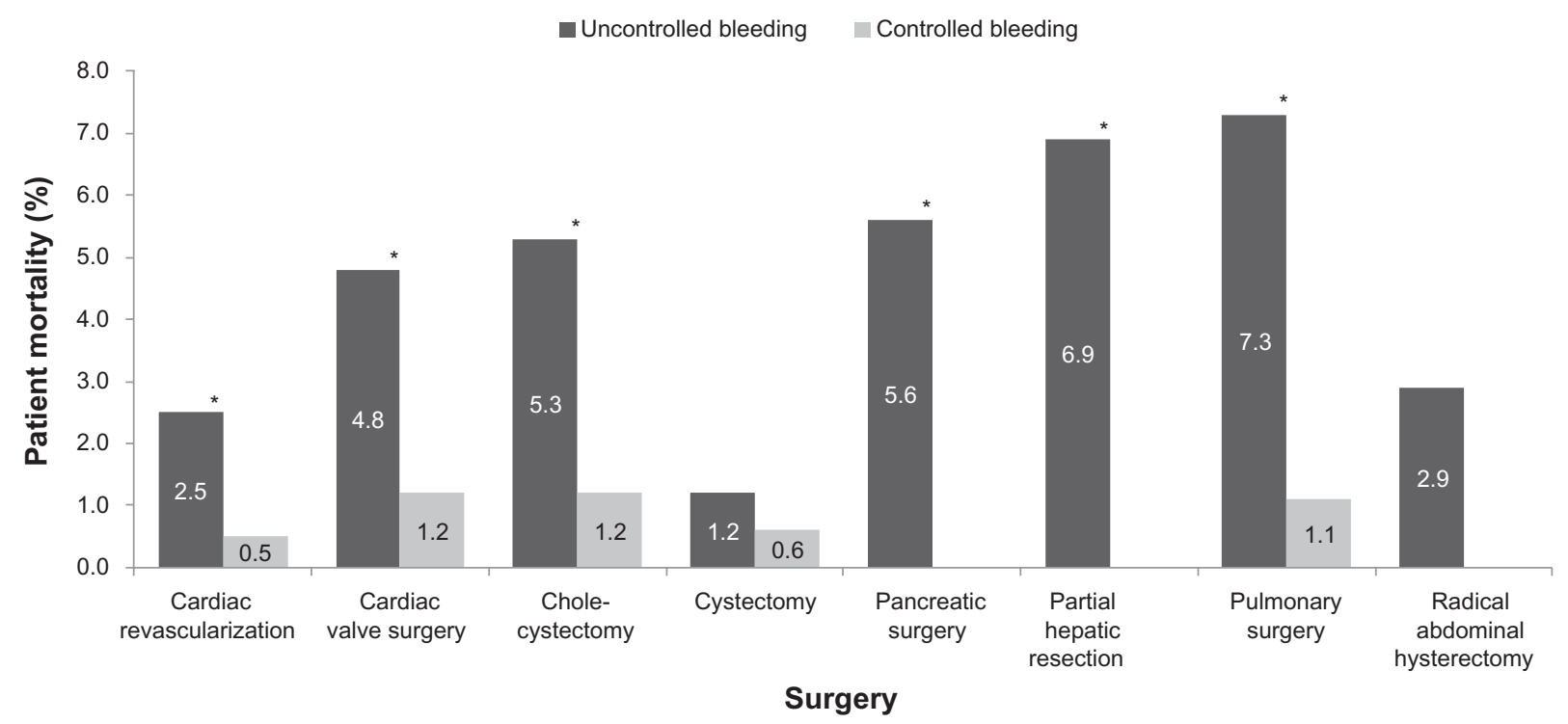

Figure 3 Patient mortality, stratified by surgery type and presence or absence of uncontrolled bleeding despite hemostat use. Note: *Statistically significant $(P<0.001)$. 
Table 3 Unadjusted mean (SD) costs and resource use, stratified by surgical procedure and presence or absence of uncontrolled bleeding despite hemostat use

\begin{tabular}{|c|c|c|c|c|c|c|c|c|}
\hline Surgery type & $\begin{array}{l}\text { All-cause } \\
\text { cost, US\$ } \\
\text { (SD) }\end{array}$ & $\begin{array}{l}\text { Cost of } \\
\text { hemostatic } \\
\text { agent, US\$ } \\
\text { (SD) }\end{array}$ & $\begin{array}{l}\text { LOS, } \\
\text { days } \\
\text { (SD) }\end{array}$ & $\begin{array}{l}\text { ICU stay, } \\
\text { days } \\
\text { (SD) }\end{array}$ & $\begin{array}{l}\text { Operation } \\
\text { time, minutes } \\
\text { (SD) }\end{array}$ & $\begin{array}{l}\text { Reoperation, } \\
\text { N (\%) }\end{array}$ & $\begin{array}{l}\text { Infection, } \\
\text { N (\%) }\end{array}$ & $\begin{array}{l}\text { Ventilator } \\
\text { use, } \\
\text { N (\%) }\end{array}$ \\
\hline \multicolumn{9}{|c|}{ Cardiac revascularization } \\
\hline Uncontrolled & $44,327(30,565)$ & $406(531)$ & $7.8(6.4)$ & $5.7(6.4)$ & $332.3(129.0)$ & 989 (13.9) & $\mathrm{I}, 818(25.5)$ & $6,84 \mid(95.9)$ \\
\hline Controlled & $35,125(17,601)$ & $254(329)$ & $5.7(3.4)$ & $3.6(3.8)$ & $312.5(143.5)$ & $372(6.6)$ & $64 I(I 1.3)$ & 5,177 (9I.4) \\
\hline$P$-value & $<0.001$ & $<0.001$ & $<0.001$ & $<0.001$ & $<.0001$ & $<0.001$ & $<0.001$ & $<0.001$ \\
\hline \multicolumn{9}{|c|}{ Cardiac valve surgery } \\
\hline Uncontrolled & $6 I, 323(44,|5|)$ & $508(692)$ & $10(8.2)$ & $6.8(8.8)$ & $376.1(168.1)$ & $\mathrm{I}, 464(27.0)$ & $1,613(29.8)$ & $5,219(96.3)$ \\
\hline Controlled & $45,593(25,559)$ & $311(395)$ & $6.8(4.5)$ & $4.0(4.6)$ & 342.5 (179.9) & $365(14.1)$ & $350(13.5)$ & $2,426(93.4)$ \\
\hline$P$-value & $<0.001$ & $<0.001$ & $<0.001$ & $<0.001$ & $<0.001$ & $<0.001$ & $<0.001$ & $<0.001$ \\
\hline \multicolumn{9}{|l|}{ Cholecystectomy } \\
\hline Uncontrolled & $29,582(27,167)$ & $287(387)$ & $8.7(8.3)$ & $5.6(6.9)$ & $196.0(431.8)$ & $104(17.1)$ & $260(42.7)$ & I8I (29.7) \\
\hline Controlled & $17,180(13,448)$ & $203(275)$ & $5.0(3.5)$ & $3.1(3.3)$ & I73.7 (I29.6) & $71(7.3)$ & $207(21.4)$ & $79(8.2)$ \\
\hline$P$-value & $<0.001$ & $<0.001$ & $<0.001$ & $<0.001$ & 0.222 & $<0.00$ I & $<0.001$ & $<0.001$ \\
\hline \multicolumn{9}{|l|}{ Cystectomy } \\
\hline Uncontrolled & $40,238(62,047)$ & $314(372)$ & $12(12.6)$ & $4.4(5.1)$ & 389.7 (I50.2) & $36(14.3)$ & $70(27.8)$ & 47 (I8.7) \\
\hline Controlled & $29,717(|8,43|)$ & $352(533)$ & $9.0(4.9)$ & $3.0(2.9)$ & $484.3(1320.8)$ & II (6.4) & $26(15.2)$ & $20(11.7)$ \\
\hline$P$-value & 0.012 & 0.424 & $<0.001$ & 0.010 & 0.358 & 0.012 & 0.002 & 0.055 \\
\hline \multicolumn{9}{|c|}{ Pancreatic surgery } \\
\hline Uncontrolled & $58,891(49,789)$ & $457(618)$ & $17(13.2)$ & $7.0(9.1)$ & $450.5(155.0)$ & $63(27.2)$ & $95(40.9)$ & $96(4 \mid .4)$ \\
\hline Controlled & $37,001(28,276)$ & $368(377)$ & $10(8.4)$ & $3.5(6.9)$ & $437.2(168.6)$ & $16(6.9)$ & $57(24.6)$ & $31(13.4)$ \\
\hline$P$-value & $<0.001$ & 0.063 & $<0.001$ & $<0.001$ & 0.378 & $<0.00$ I & $<0.001$ & $<0.001$ \\
\hline \multicolumn{9}{|c|}{ Partial hepatic resection } \\
\hline Uncontrolled & $42,8 \mid 9(54,5 \mid 5)$ & 674 (899) & $9.9(10.4)$ & $5.9(8.5)$ & $319.2(140.4)$ & $25(10.7)$ & $59(25.3)$ & 65 (27.9) \\
\hline Controlled & $21,035(10,874)$ & $45 I(4 I I)$ & $5.5(2.7)$ & $2.1(1.9)$ & $294.9(233.1)$ & $18(4.7)$ & $46(11.9)$ & $24(6.2)$ \\
\hline$P$-value & $<0.001$ & $<0.001$ & $<0.001$ & $<0.001$ & 0.107 & 0.004 & $<0.001$ & $<0.001$ \\
\hline \multicolumn{9}{|c|}{ Pulmonary surgery } \\
\hline Uncontrolled & $40,211(33,239)$ & $799(1,053)$ & II (9.6) & $8.5(1 \mathrm{I} .6)$ & $270.8(118.2)$ & $83(27.5)$ & II 6 (38.4) & $120(39.7)$ \\
\hline Controlled & $24,36 \mid(\mid 4,893)$ & $347(592)$ & $7.1(4.3)$ & $3.6(3.7)$ & $249.3(94.7)$ & $57(8.7)$ & $106(16.3)$ & $122(18.7)$ \\
\hline$P$-value & $<0.001$ & $<0.001$ & $<0.001$ & $<0.001$ & 0.006 & $<0.00$ I & $<0.001$ & $<0.001$ \\
\hline \multicolumn{9}{|c|}{ Radical abdominal hysterectomy } \\
\hline Uncontrolled & $24,203(17,854)$ & $592(625)$ & $7.1(5.8)$ & $5.2(6.4)$ & $280.4(116.9)$ & $4(5.8)$ & $26(37.7)$ & $10(14.5)$ \\
\hline Controlled & $14,420(7,444)$ & $361(515)$ & $4.1(2.5)$ & $2.2(2.1)$ & $242.8(100.2)$ & $3(2.4)$ & $24(18.9)$ & $4(3.1)$ \\
\hline$P$-value & $<0.001$ & 0.006 & $<0.001$ & $<0.001$ & $<0.001$ & 0.245 & 0.004 & 0.007 \\
\hline
\end{tabular}

Abbreviations: Controlled, controlled bleeding despite hemostat use; uncontrolled, uncontrolled bleeding despite hemostat use; ICU, intensive care unit; LOS, length of stay; N, number of patients; SD, standard deviation.

Table 4 Mean adjusted all-cause costs $(95 \% \mathrm{Cl})$ and mean adjusted hospital LOS $(95 \% \mathrm{Cl})$ for controlled versus uncontrolled bleeding in patients treated with hemostatic agents, stratified by surgical procedure

\begin{tabular}{|c|c|c|c|c|c|c|}
\hline \multirow[t]{2}{*}{ Surgical category } & \multicolumn{3}{|c|}{ Adjusted all-cause cost, US\$ $(95 \% \mathrm{CI})$} & \multicolumn{3}{|c|}{ Adjusted length of stay, days $(95 \% \mathrm{Cl})$} \\
\hline & $\begin{array}{l}\text { Bleeding not } \\
\text { controlled despite } \\
\text { HA }\end{array}$ & $\begin{array}{l}\text { Bleeding controlled } \\
\text { with HA }\end{array}$ & $P$-value & $\begin{array}{l}\text { Bleeding not } \\
\text { controlled despite } \\
\text { HA }\end{array}$ & $\begin{array}{l}\text { Bleeding controlled } \\
\text { with HA }\end{array}$ & $P$-value \\
\hline Cardiac revascularization & $44,198(43,610-44,785)$ & $35,288(34,624-35,95 I)$ & $<0.001$ & $7.7(7.5-7.8)$ & $5.9(5.8-6.1)$ & $<0.001$ \\
\hline Cardiac valve Surgery & $60,53 \mid(59,510-61,552)$ & $47,245(45,746-48,745)$ & $<0.001$ & $9.7(9.5-9.9)$ & $7.2(7.0-7.5)$ & $<0.001$ \\
\hline Cholecystectomy & $29,101(27,532-30,670)$ & $17,483(16,248-18,7 \mid 8)$ & $<0.001$ & $8.4(7.9-8.9)$ & $5.2(4.8-5.5)$ & $<0.001$ \\
\hline Cystectomy & $4 I, 708(35,54 I-47,876)$ & $27,55 \mid(19,976-35,126)$ & 0.006 & $12.5(\mid 1.2-13.7)$ & $8.8(7.2-10.3)$ & $<0.001$ \\
\hline Pancreatic surgery & $58,853(53,503-64,203)$ & $37,039(31,689-42,389)$ & $<0.001$ & $16.2(14.7-17.7)$ & $10.8(9.3-12.3)$ & $<0.001$ \\
\hline Partial hepatic resection & $43,649(39,188-48,111)$ & $20,535(17,106-23,964)$ & $<0.001$ & $9.8(8.9-10.7)$ & $5.6(4.9-6.2)$ & $<0.001$ \\
\hline Pulmonary surgery & $40,416(37,886-42,946)$ & $24,266(22,564-25,968)$ & $<0.001$ & $11.3(10.5-12.0)$ & $7.1(6.6-7.6)$ & $<0.001$ \\
\hline $\begin{array}{l}\text { Radical abdominal } \\
\text { hysterectomy }\end{array}$ & $23,266(20,458-26,075)$ & $14,929(|2,89|-\mid 6,967)$ & $<0.001$ & $6.8(5.8-7.7)$ & $4.3(3.6-5.0)$ & $<0.001$ \\
\hline
\end{tabular}

Note: Values presented as mean $(95 \% \mathrm{Cl})$.

Abbreviations: $\mathrm{Cl}$, confidence interval; LOS, length of stay; HA, hemostatic agent. 
alleviate this burden. The EVARREST ${ }^{\circledR}$ fibrin sealant patch is one novel bioabsorbable combination product composed of human fibrinogen and thrombin along with a flexible composite patch that provides mechanical integrity and supports clot formation. ${ }^{35}$ EVARREST $^{\circledR}$ is supported by several clinical studies across challenging bleeding populations demonstrating rapid onset of action with high hemostasis efficacy. ${ }^{27,36}$ A recent economic evaluation also showed that this new fibrin sealant patch was predicted to be cost saving in problematic surgical bleeding for hospital stakeholders due to hospital resources averted, such as transfusions and bleeding retreatment, versus standard of care. ${ }^{37}$ Such results are particularly relevant in light of the findings of the current study showing significantly greater hemostat costs in uncontrolled bleeding cohorts. Several additional new hemostatic agents have also been developed that are currently undergoing clinical trials. Examples of these products include Veriset ${ }^{\mathrm{TM}}$ hemostatic patch (Covidien Inc., Mansfield, MA, USA), Fibrocaps ${ }^{\text {TM }}$ (ProFibrix, Leiden, the Netherlands), and Hemopatch Sealing Hemostat (Baxter International, Deerfield, IL, USA). These products have numerous ongoing trials for the treatment of surgical bleeding across a wide range of surgery types with demonstrated effectiveness in some trials. ${ }^{38-41}$ No economic evaluations have been published to date with these products.

\section{Limitations}

This study is not without limitations. First, it was retrospective; therefore, it was not possible to control for all potential confounding variables as can be done within a randomized controlled trial. Second, limitations of this study include those common to all claims-based studies. Specifically, the data for this study were derived from hospital discharge records designed to be used for billing rather than research. There is some degree of miscoding that is common in these records, and the records were not independently validated. Furthermore, data such as these miss clinical details that ideally would be used to further explain study results. For example, there are no disease-specific measures of severity, no clinical assessments of preoperative risk (eg, hematocrit levels), and no data on surgeon's skill level and techniques used. This information could not be captured and could not be evaluated or controlled for, as this was a retrospective database analysis. However, the potential impact of several patient and hospital characteristics was controlled for in adjusted multivariate analyses for the all-cause hospital costs as well as length of hospital stay, with adjustment having little impact on overall conclusions. Third, data are limited to the index hospitalization, so pre-existing comorbidities are not well captured. Fourth, data were only collected on hemostat class (eg, active, fibrin sealant, mechanical), and therefore it was not possible to conduct analyses on the association between specific hemostat products and bleeding control. Such information would have been useful for assessing the extent to which multiple product use or more expensive products contributed to the significantly higher total hemostat cost per patient in the uncontrolled bleeding cohort.

\section{Conclusion}

Despite the use of hemostatic agents, uncontrolled bleeding is common and is associated with significantly higher costs; longer hospitalization; and higher rates of reoperation and mortality in multiple major surgical procedures compared to controlled bleeding. There is an unmet need for newer hemostats that can improve clinical outcomes in surgery and minimize the economic burden to hospitals and payers. Future studies need to assess the clinical and economic impact of newer, highly efficacious hemostats in real-world, difficult-to-control bleeding populations.

\section{Acknowledgments}

Cornerstone Research Group (SH, NF) received funding from Ethicon Inc., to conduct the study and prepare the manuscript. The Partnership for Health Analytic Research (PHAR) (MSB, EC) also received funding from Ethicon Inc., to conduct this study. MC is an employee of Ethicon Inc. The authors would like to acknowledge Gordon Sun for assisting in the study design and results interpretation, and Bryanna Tibensky for assisting with the drafting of the manuscript.

\section{Author contributions}

$\mathrm{MC}$ was involved in the study protocol design and development, data acquisition, and critical review of the manuscript. $\mathrm{NF}$ and $\mathrm{SH}$ were involved in data analysis/interpretation and development of the manuscript draft. MSB was involved in study protocol design and development, data analysis/ interpretation, and critical review of the manuscript. EC was involved in study protocol design and development, data analysis/interpretation, and critical review of the manuscript. All authors have given final approval for the manuscript and agree to be accountable for all aspects of the work in ensuring that questions related to the accuracy or integrity of any part of the work are appropriately investigated and resolved.

\section{Disclosure}

The authors report no conflicts of interest in this work. 


\section{References}

1. Dyke C, Aronson S, Dietrich W, et al. Universal definition of perioperative bleeding in adult cardiac surgery. J Thorac Cardiovasc Surg. 2014;147(5):1458-1463. e1.

2. Ercan M, Bostanci EB, Ozer I, et al. Postoperative hemorrhagic complications after elective laparoscopic cholecystectomy in patients receiving long-term anticoagulant therapy. Langenbecks Arch Surg. 2010;395(3):247-253.

3. Marietta M, Facchini L, Pedrazzi P, Busani S, Torelli G. Pathophysiology of bleeding in surgery. Transplant Proc. 2006;38(3):812-814.

4. Shander A. Financial and clinical outcomes associated with surgical bleeding complications. Surgery. 2007;142(4 Suppl):S20-S25.

5. Stone GW, Clayton TC, Mehran R, et al. Impact of major bleeding and blood transfusions after cardiac surgery: analysis from the Acute Catheterization and Urgent Intervention Triage strategY (ACUITY) trial. Am Heart J. 2012;163(3):522-529.

6. Levy JH, Dutton RP, Hemphill JC 3rd, et al. Multidisciplinary approach to the challenge of hemostasis. Anesth Analg. 2010;110(2):354-364.

7. Parekh AK, Barton MB. The challenge of multiple comorbidity for the US health care system. JAMA. 2010;303(13):1303-1304.

8. United Nations. World Population Ageing: 1950-2050. In: Division DoEaSA-P, ed. New York: United Nations Publications; 2001:1-45.

9. Boucher BA, Traub O. Achieving hemostasis in the surgical field. Pharmacotherapy. 2009;29(7 Pt 2):2S-7S.

10. Gabay M. Absorbable hemostatic agents. Am J Health Syst Pharm. 2006;63(13):1244-1253.

11. Kulkarni R. Alternative and topical approaches to treating the massively bleeding patient. Clin Adv Hematol Ooncol. 2004;2(7):428, 431.

12. Samudrala S. Topical hemostatic agents in surgery: a surgeon's perspective. AORN J. 2008;88(3):S2-S11.

13. Voils S. Pharmacologic interventions for the management of critical bleeding. Pharmacotherapy. 2007;27(9 Pt 2):69S-84S.

14. Wright JD, Ananth CV, Lewin SN, et al. Patterns of use of hemostatic agents in patients undergoing major surgery. J Surg Res. 2014;186(1):458-466.

15. Christensen MC, Krapf S, Kempel A, von Heymann C. Costs of excessive postoperative hemorrhage in cardiac surgery. J Thorac Cardiovasc Surg. 2009;138(3):687-693.

16. Marietta M, Pedrazzi P, Girardis M, Luppi M. Massive bleeding: are we doing our best? Transfus Apher Sci. 2011;45(3):287-290.

17. Rossaint R, Cerny V, Coats TJ, et al. Key issues in advanced bleeding care in trauma. Shock. 2006;26(4):322-331.

18. Schreiber MA, Neveleff DJ. Achieving hemostasis with topical hemostats: making clinically and economically appropriate decisions in the surgical and trauma settings. AORN J. 2011;94(5):S1-S20.

19. Spotnitz WD. Efficacy and safety of fibrin sealant for tissue adherence in facial rhytidectomy. Clin Cosmet Investig Dermatol. 2012;5: 43-51.

20. Spotnitz WD, Burks S. Hemostats, sealants, and adhesives: components of the surgical toolbox. Transfusion. 2008;48(7):1502-1516.

21. Rossaint R, Bouillon B, Cerny V, et al. Management of bleeding following major trauma: an updated European guideline. Crit Care (London, England). 2010;14(2):R52.

22. Claridge JA, Sawyer RG, Schulman AM, McLemore EC, Young JS. Blood transfusions correlate with infections in trauma patients in a dose-dependent manner. Am Surg. 2002;68(7):566-572.

23. Stokes ME, Ye X, Shah M, et al. Impact of bleeding-related complications and/or blood product transfusions on hospital costs in inpatient surgical patients. BMC Health Serv Res. 2011;11:135.
24. Lauzier F, Arnold DM, Rabbat C, et al. Risk factors and impact of major bleeding in critically ill patients receiving heparin thromboprophylaxis. Intensive Care Med. 2013;39(12):2135-2143.

25. Bochicchio GV, Napolitano L, Joshi M, Bochicchio K, Meyer W, Scalea TM. Outcome analysis of blood product transfusion in trauma patients: a prospective, risk-adjusted study. World J Surg. 2008; 32(10):2185-2189.

26. Doussau A, Perez P, Puntous M, et al. Fresh-frozen plasma transfusion did not reduce 30-day mortality in patients undergoing cardiopulmonary bypass cardiac surgery with excessive bleeding: the PLASMACARD multicenter cohort study. Transfusion. 2014;54(4):1114-1124.

27. Fischer CP, Bochicchio G, Shen J, Patel B, Batiller J, Hart JC. A prospective, randomized, controlled trial of the efficacy and safety of fibrin pad as an adjunct to control soft tissue bleeding during abdominal, retroperitoneal, pelvic, and thoracic surgery. $\mathrm{J} \mathrm{Am} \mathrm{Coll}$ Surg. 2013;217(3):385-393.

28. Saif R, Jacob M, Robinson S, et al. Use of fibrin-based sealants and gelatin-matrix hemostats in laparoscopic liver surgery. Surg Laparosc Endosc Percutan Tech. 2011;21(3):131-141.

29. Spahn DR, Rossaint R. Coagulopathy and blood component transfusion in trauma. BrJ Anaesth. 2005;95(2):130-139.

30. Aubourg R, Putzolu J, Bouche S, et al. Surgical hemostatic agents: assessment of drugs and medical devices. J Visc Surg. 2011;148(6): e405-e408.

31. Carless PA, Henry DA, Anthony DM. Fibrin sealant use for minimising peri-operative allogeneic blood transfusion. Cochrane Database Syst Rev. 2003(2):CD004171.

32. Rousou JA. Use of fibrin sealants in cardiovascular surgery: a systematic review. J Card Surg. 2013;28(3):238-247.

33. Sanjay P, Watt DG, Wigmore SJ. Systematic review and meta-analysis of haemostatic and biliostatic efficacy of fibrin sealants in elective liver surgery. J Gastrointest Surg. 2013;17(4):829-836.

34. Wang H, Shan L, Zeng H, Sun M, Hua Y, Cai Z. Is fibrin sealant effective and safe in total knee arthroplasty? A meta-analysis of randomized trials. J Orthop Surg Res. 2014;16(9):36.

35. Hunt BJ. Bleeding and coagulopathies in critical care. $N$ Engl J Med. 2014;370(9):847-859.

36. Koea JB, Batiller J, Patel B, et al. A phase III, randomized, controlled, superiority trial evaluating the fibrin pad versus standard of care in controlling parenchymal bleeding during elective hepatic surgery. $H P B$ (Oxford). 2013;15(1):61-70.

37. Corral MFN, Hollmann S, et al. Cost analysis of a fibrin sealant patch for mild, moderate, and problematic soft tissue surgical bleeding: a hospital perspective. Value in Health. 2013:A380. PSY315.

38. Ollinger R, Mihaljevic AL, Schuhmacher C, et al. A multicentre, randomized clinical trial comparing the Veriset haemostatic patch with fibrin sealant for the management of bleeding during hepatic surgery. HPB (Oxford). 2013;15(7):548-558.

39. Verhoef C, Singla N, Moneta G, et al. Fibrocaps for surgical hemostasis: two randomized, controlled phase II trials. J Surg Res. Epub December 10, 2014.

40. Bochicchio GV, Gupta N, Porte RJ, et al. The FINISH-3 trial: a phase 3, international, randomized, single-blind, controlled trial of topical fibrocaps in intraoperative surgical hemostasis. J Am Coll Surg. 2015; 220(1):70-81.

41. Fingerhut A, Uranues S, Ettorre GM, et al. European Initial Hands-On Experience with HEMOPATCH, a Novel Sealing Hemostatic Patch: Application in General, Gastrointestinal, Biliopancreatic, Cardiac, and Urologic Surgery. Surg Technol Int. 2014;25:29-35. 


\section{Supplementary materials}

Table SI Selected primary surgical procedures

\begin{tabular}{|c|c|}
\hline $\begin{array}{l}\text { ICD-9-CM } \\
\text { procedure }\end{array}$ & Description \\
\hline \multicolumn{2}{|c|}{ Cardiac revascularization surgery } \\
\hline 36.03 & Open chest coronary artery angioplasty \\
\hline $36.1 x$ & Bypass anastomosis for heart revascularization \\
\hline 36.2 & Heart revascularization by arterial implant \\
\hline 36.32 & Other transmyocardial revascularization \\
\hline 36.39 & Other heart revascularization \\
\hline \multicolumn{2}{|c|}{ Cardiac valve surgery } \\
\hline $35.1 x$ & Open heart valvuloplasty without replacement \\
\hline $35.2 x$ & Replacement of heart valve \\
\hline $35.3 x$ & Operations on structures adjacent to heart valves \\
\hline 35.99 & Other operations on valves of heart \\
\hline \multicolumn{2}{|c|}{ Cholecystectomy } \\
\hline 51.21 & $\begin{array}{l}\text { Other partial cholecystectomy (revision of prior } \\
\text { cholecystectomy) }\end{array}$ \\
\hline 51.22 & Cholecystectomy (open) \\
\hline \multicolumn{2}{|l|}{ Cystectomy } \\
\hline 57.71 & Radical cystectomy \\
\hline 57.79 & Other total cystectomy \\
\hline \multicolumn{2}{|c|}{ Pancreatic surgery } \\
\hline 52.51 & Proximal pancreatectomy \\
\hline 52.52 & Distal pancreatectomy \\
\hline 52.53 & Radical subtotal pancreatectomy \\
\hline 52.59 & Other partial pancreatectomy \\
\hline 52.6 & Total pancreatectomy \\
\hline 52.7 & $\begin{array}{l}\text { Radical pancreaticoduodenectomy (Whipple } \\
\text { procedure) }\end{array}$ \\
\hline \multicolumn{2}{|c|}{ Partial hepatic resection } \\
\hline 50.22 & Partial hepatectomy (wedge resection of liver) \\
\hline 50.3 & Lobectomy of liver \\
\hline \multicolumn{2}{|c|}{ Pulmonary surgery } \\
\hline 32.39 & $\begin{array}{l}\text { Other and unspecified segmental resection of } \\
\text { lung }\end{array}$ \\
\hline 32.49 & Other lobectomy of lung \\
\hline 32.59 & Other and unspecified pneumonectomy \\
\hline \multicolumn{2}{|c|}{ Radical abdominal hysterectomy } \\
\hline 68.69 & $\begin{array}{l}\text { Other and unspecified radical abdominal } \\
\text { hysterectomy }\end{array}$ \\
\hline
\end{tabular}

Table S2 Hemostatic agents

\begin{tabular}{|c|c|}
\hline Category & Products \\
\hline Mechanical & 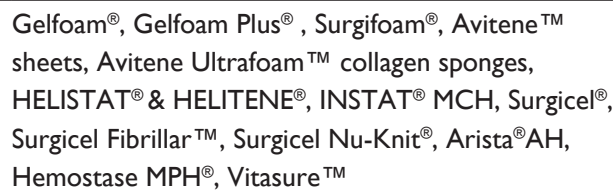 \\
\hline Active & Thrombin-JMI ${ }^{\circledast}$, Evithrom ${ }^{\circledR}$, Recothrom ${ }^{\circledR}$ \\
\hline Flowable & Floseal $^{\circledR}$, Surgiflo ${ }^{\circledR}$ \\
\hline Fibrin sealant & $\begin{array}{l}\text { Evicel }^{\circledR} \text {, Beriplast }^{\circledR}, \text { TachoSil }^{\circledR}, \text { Tisseel }^{\mathrm{TM}}, \text { Artiss, } \\
\text { Vitagel }^{\mathrm{TM}} \text {, Vivostat }^{\circledR}\end{array}$ \\
\hline
\end{tabular}

Table S3 Major bleeding events

\begin{tabular}{|c|c|}
\hline $\begin{array}{l}\text { ICD-9-CM diagnosis } \\
\text { or procedure code }\end{array}$ & Description \\
\hline \multicolumn{2}{|l|}{ Diagnosis of bleeding } \\
\hline 998.11 & Hemorrhage complicating a procedure \\
\hline 998.12 & Hematoma complicating a procedure \\
\hline \multicolumn{2}{|c|}{ Procedures to control bleeding } \\
\hline 34.09 & $\begin{array}{l}\text { Other incision of pleura, including creation of } \\
\text { pleural window for drainage, intercostal stab, } \\
\text { open chest drainage }\end{array}$ \\
\hline 39.98 & $\begin{array}{l}\text { Control of hemorrhage not otherwise } \\
\text { specified }\end{array}$ \\
\hline 44.44 & $\begin{array}{l}\text { Transcatheter embolization for gastric or } \\
\text { duodenal bleeding }\end{array}$ \\
\hline 44.49 & $\begin{array}{l}\text { Other control of hemorrhage of stomach or } \\
\text { duodenum - that with gastronomy }\end{array}$ \\
\hline 54.19 & $\begin{array}{l}\text { Other laparotomy: drainage of } \\
\text { intraperitoneal abscess or hematoma }\end{array}$ \\
\hline 39.41 & $\begin{array}{l}\text { Control of hemorrhage following vascular } \\
\text { surgery }\end{array}$ \\
\hline 34.03 & Reopening of recent thoracotomy site \\
\hline 54.12 & $\begin{array}{l}\text { Reopening of recent laparotomy site for: } \\
\text { control of hemorrhage, exploration, incision } \\
\text { of hematoma }\end{array}$ \\
\hline 57.93 & $\begin{array}{l}\text { Control of (postoperative) hemorrhage of } \\
\text { bladder }\end{array}$ \\
\hline Charges billed for & Hemovac drainage devices \\
\hline \multicolumn{2}{|l|}{ Erythropoietin } \\
\hline Charges billed for & Epogen, Procrit, Aranesp, Darbepoetin \\
\hline \multicolumn{2}{|l|}{ Blood products } \\
\hline 99.00 & $\begin{array}{l}\text { Perioperative autologous transfusion of } \\
\text { whole blood or blood components }\end{array}$ \\
\hline 99.02 & $\begin{array}{l}\text { Transfusion of previously collected } \\
\text { autologous blood }\end{array}$ \\
\hline 99.03 & Other transfusion of whole blood \\
\hline 99.04 & Transfusion of packed cells \\
\hline 99.05 & Transfusion of platelets \\
\hline 99.07 & Transfusion of other serum \\
\hline 99.08 & Transfusion of blood expander \\
\hline 99.09 & Transfusion of other substance \\
\hline Charges billed for & $\begin{array}{l}\text { Cryoprecipitates, fresh frozen plasma, red } \\
\text { blood cells, plasma, platelets, whole blood }\end{array}$ \\
\hline
\end{tabular}


Table S4 Infections

\begin{tabular}{ll}
\hline $\begin{array}{l}\text { ICD-9-CM diagnosis } \\
\text { code }\end{array}$ & Description \\
\hline $\begin{array}{ll}\text { Postoperative infections } \\
998.5 x\end{array}$ & $\begin{array}{l}\text { Postoperative infection } \\
\text { Infection and inflammatory reaction due to } \\
\text { internal prosthetic device, implant, and graft }\end{array}$
\end{tabular}

Infection due to medical care

999.3x

Other infection: infection due to central venous catheter; infection following other infusion, injection, transfusion, or vaccination

Septicemia

038.x

785.52

995.91

995.92

998.0

Other bacterial infections

040.0

$040.8 \mathrm{x}$

$041 . x$

790.7

Skin infections

682.x

686. $x$

Urinary tract infections

112.2

590.1

590.3

$590.8 \mathrm{x}$

590.9

595.0

595.3

599.0

996.64

Pneumonia

039.1

112.4

117.9

136.3

466.19

480. $x$

481

482. $x$

483.x

484. $x$

485

486

487.0
Septicemia

Septic shock

Sepsis

Severe sepsis

Postoperative shock

Gas gangrene

Bacterial infection in conditions classified elsewhere and of unspecified site

Bacteremia

Other cellulitis and abscess

Other local infections of skin and

subcutaneous tissue

Candidiasis of other urogenital sites

Acute pyelonephritis

Pyeloureteritis cystica

Other pyelonephritis or pyonephrosis, not specified as acute or chronic

Infection of kidney, unspecified

Acute cystitis

Trigonitis

Urinary tract infection, site not specified

Infection due to indwelling urinary catheter

Pulmonary actinomycotic infections

Candidiasis of lung

Other and unspecified mycoses

Pneumocystosis

Acute bronchiolitis due to other infectious organisms

Viral pneumonia

Pneumococcal pneumonia (Streptococcus

pneumoniae pneumonia)

Other bacterial pneumonia

Pneumonia due to other specified organism

Pneumonia in infectious diseases classified

elsewhere

Bronchopneumonia, organism unspecified

Pneumonia, organism unspecified

With pneumonia
Other specified bacterial diseases
Table S4 (Continued)

\begin{tabular}{|c|c|}
\hline $\begin{array}{l}\text { ICD-9-CM diagnosis } \\
\text { code }\end{array}$ & Description \\
\hline 507.x & Pneumonitis due to solids and liquids \\
\hline 513.0 & Abscess of lung \\
\hline 516.8 & $\begin{array}{l}\text { Other specified alveolar and parietoalveolar } \\
\text { pneumonopathies }\end{array}$ \\
\hline $997.3 x$ & Respiratory complications \\
\hline \multicolumn{2}{|l|}{ Gynecological infections } \\
\hline 614.0 & Acute salpingitis and oophoritis \\
\hline 614.2 & $\begin{array}{l}\text { Salpingitis and oophoritis not specified as } \\
\text { acute, subacute, or chronic }\end{array}$ \\
\hline 614.3 & Acute parametritis and pelvic cellulitis \\
\hline 614.4 & $\begin{array}{l}\text { Chronic or unspecified parametritis and } \\
\text { pelvic cellulitis }\end{array}$ \\
\hline 614.5 & $\begin{array}{l}\text { Acute or unspecified pelvic peritonitis, } \\
\text { female }\end{array}$ \\
\hline 614.6 & $\begin{array}{l}\text { Pelvic peritoneal adhesions, female } \\
\text { (postoperative) (postinfection) }\end{array}$ \\
\hline 614.8 & $\begin{array}{l}\text { Other specified inflammatory disease of } \\
\text { female pelvic organs and tissues }\end{array}$ \\
\hline 614.9 & $\begin{array}{l}\text { Unspecified inflammatory disease of female } \\
\text { pelvic organs and tissues }\end{array}$ \\
\hline 615.0 & $\begin{array}{l}\text { Acute inflammatory diseases of uterus, } \\
\text { except cervix }\end{array}$ \\
\hline 615.9 & Unspecified inflammatory disease of uterus \\
\hline $670.0 x$ & Major puerperal infection \\
\hline $672.0 x$ & $\begin{array}{l}\text { Pyrexia of unknown origin during the } \\
\text { puerperium }\end{array}$ \\
\hline \multicolumn{2}{|l|}{ Septic embolism } \\
\hline $673.3 x$ & Obstetrical pyemic and septic embolism \\
\hline \multicolumn{2}{|l|}{ Fever } \\
\hline $780.6 x$ & $\begin{array}{l}\text { Fever and other physiologic disturbances of } \\
\text { temperature regulation }\end{array}$ \\
\hline
\end{tabular}

(Continued) 
Table S5 Transfusion coding descriptions

\begin{tabular}{|c|c|}
\hline $\begin{array}{l}\text { ICD-9-CM procedure or } \\
\text { standard charge code }\end{array}$ & Description \\
\hline \multicolumn{2}{|l|}{ Transfusion of platelets } \\
\hline 99.05 & Transfusion of platelets \\
\hline \multicolumn{2}{|c|}{ Transfusion of coagulation factors } \\
\hline 99.06 & Transfusion of coagulation factors \\
\hline \multicolumn{2}{|l|}{ Other transfusion } \\
\hline \multirow[t]{2}{*}{99.00} & Perioperative autologous transfusion \\
\hline & of whole blood or blood components \\
\hline 99.01 & Autologous whole blood transfusion \\
\hline 99.02 & $\begin{array}{l}\text { Transfusion of previously collected } \\
\text { autologous blood }\end{array}$ \\
\hline 99.03 & Other transfusion of whole blood \\
\hline 99.04 & Transfusion of packed cells \\
\hline 99.07 & Transfusion of other serum \\
\hline 99.08 & Transfusion of blood expander \\
\hline 99.09 & Transfusion of other substance \\
\hline V58.2 & Blood transfusion, no diagnosis \\
\hline 380381000010000 & Red Cells Packed I Unit \\
\hline 380381000010007 & Red Cells Packed 7 Units \\
\hline 380381000010008 & Red Cells Packed 8 Units \\
\hline 380381000010009 & Red Cells Packed 9 Units \\
\hline 380381000010010 & Red Cells Packed I0 Units \\
\hline 380381000020000 & Red Cells Packed 2 Units \\
\hline 380381000030000 & Red Cells Packed 3 Units \\
\hline 380381000040000 & Red Cells Packed 4 Units \\
\hline 380381000050000 & Red Cells Packed 5 Units \\
\hline 380381000060000 & Red Cells Packed 6 Units \\
\hline 380381000210000 & Red Cells Autologous I Unit \\
\hline 380381000210005 & Red Cells Autologous 5 Units \\
\hline 380381000210006 & Red Cells Autologous 6 Units \\
\hline 380381000210007 & Red Cells Autologous 7 Units \\
\hline 380381000210008 & Red Cells Autologous 8 Units \\
\hline 380381000210009 & Red Cells Autologous 9 Units \\
\hline 380381000210010 & Red Cells Autologous 10 Units \\
\hline 380381000220000 & Red Cells Autologous 2 Units \\
\hline 380381000230000 & Red Cells Autologous 3 Units \\
\hline 380381000240000 & Red Cells Autologous 4 Units \\
\hline 380381000310000 & Red Cells Leukocyte Poor I Unit \\
\hline 380381000310005 & Red Cells Leukocyte Poor 5 Units \\
\hline 380381000310006 & Red Cells Leukocyte Poor 6 Units \\
\hline 380381000310007 & Red Cells Leukocyte Poor 7 Units \\
\hline 380381000310008 & Red Cells Leukocyte Poor 8 Units \\
\hline 380381000310009 & Red Cells Leukocyte Poor 9 Units \\
\hline 380381000310010 & Red Cells Leukocyte Poor 10 Units \\
\hline 380381000320000 & Red Cells Leukocyte Poor 2 Units \\
\hline 380381000330000 & Red Cells Leukocyte Poor 3 Units \\
\hline 380381000340000 & Red Cells Leukocyte Poor 4 Units \\
\hline 380381000410000 & Red Cells Washed I Unit \\
\hline 380381000410003 & Red Cells Washed 3 Units \\
\hline 380381000410004 & Red Cells Washed 4 Units \\
\hline 380381000410005 & Red Cells Washed 5 Units \\
\hline 380381000410006 & Red Cells Washed 6 Units \\
\hline 380381000410007 & Red Cells Washed 7 Units \\
\hline 380381000410008 & Red Cells Washed 8 Units \\
\hline 380381000410009 & Red Cells Washed 9 Units \\
\hline 380381000410010 & Red Cells Washed I0 Units \\
\hline 380381000420000 & Red Cells Washed 2 Units \\
\hline
\end{tabular}

(Continued)
Table S5 (Continued)

\begin{tabular}{|c|c|}
\hline $\begin{array}{l}\text { ICD-9-CM procedure or } \\
\text { standard charge code }\end{array}$ & Description \\
\hline 380381000510000 & Red Cells Deglycerolized I Unit \\
\hline 380381000510003 & Red Cells Deglycerolized 3 Units \\
\hline 380381000510004 & Red Cells Deglycerolized 4 Units \\
\hline 380381000510005 & Red Cells Deglycerolized 5 Units \\
\hline 380381000510006 & Red Cells Deglycerolized 6 Units \\
\hline 380381000510007 & Red Cells Deglycerolized 7 Units \\
\hline 380381000510008 & Red Cells Deglycerolized 8 Units \\
\hline 380381000510009 & Red Cells Deglycerolized 9 Units \\
\hline 380381000510010 & Red Cells Deglycerolized I0 Units \\
\hline 380381000520000 & Red Cells Deglycerolized 2 Units \\
\hline 380381000610000 & Red Cells Directed I Unit \\
\hline 380381000610002 & Red Cells Directed 2 Units \\
\hline 380381000610003 & Red Cells Directed 3 Units \\
\hline 380381000610004 & Red Cells Directed 4 Units \\
\hline 380381000610005 & Red Cells Directed 5 Units \\
\hline 380381000610006 & Red Cells Directed 6 Units \\
\hline 380381000610007 & Red Cells Directed 7 Units \\
\hline 380381000610008 & Red Cells Directed 8 Units \\
\hline 380381000610009 & Red Cells Directed 9 Units \\
\hline 380381000610010 & Red Cells Directed I0 Units \\
\hline 380382000010000 & Whole Blood I Unit \\
\hline 380382000010002 & Whole Blood 2 Units \\
\hline 380382000010003 & Whole Blood 3 Units \\
\hline 380382000010004 & Whole Blood 4 Units \\
\hline 380382000010005 & Whole Blood 5 Units \\
\hline 380382000010006 & Whole Blood 6 Units \\
\hline 380382000010007 & Whole Blood 7 Units \\
\hline 380382000010008 & Whole Blood 8 Units \\
\hline 380382000010009 & Whole Blood 9 Units \\
\hline 380382000010010 & Whole Blood 10 Units \\
\hline 380382000210000 & Whole Blood Autologous I Unit \\
\hline 380382000210005 & Whole Blood Autologous 5 Units \\
\hline 380382000210006 & Whole Blood Autologous 6 Units \\
\hline 380382000210007 & Whole Blood Autologous 7 Units \\
\hline 380382000210008 & Whole Blood Autologous 8 Units \\
\hline 380382000210009 & Whole Blood Autologous 9 Units \\
\hline 380382000210010 & Whole Blood Autologous 10 Units \\
\hline 380382000220000 & Whole Blood Autologous 2 Units \\
\hline 380382000230000 & Whole Blood Autologous 3 Units \\
\hline 380382000240000 & Whole Blood Autologous 4 Units \\
\hline 380382000310000 & Whole Blood Irradiated I Unit \\
\hline 380382000310002 & Whole Blood Irradiated 2 Units \\
\hline 380382000310003 & Whole Blood Irradiated 3 Units \\
\hline 380382000310004 & Whole Blood Irradiated 4 Units \\
\hline 380382000310005 & Whole Blood Irradiated 5 Units \\
\hline 380382000310006 & Whole Blood Irradiated 6 Units \\
\hline 380382000310007 & Whole Blood Irradiated 7 Units \\
\hline 380382000310008 & Whole Blood Irradiated 8 Units \\
\hline 380382000310009 & Whole Blood Irradiated 9 Units \\
\hline 380382000310010 & Whole Blood Irradiated 10 Units \\
\hline
\end{tabular}




\section{Publish your work in this journal}

ClinicoEconomics \& Outcomes Research is an international, peerreviewed open-access journal focusing on Health Technology Assessment, Pharmacoeconomics and Outcomes Research in the areas of diagnosis, medical devices, and clinical, surgical and pharmacological intervention. The economic impact of health policy and health systems organization also constitute important areas of coverage. The manuscript management system is completely online and includes a very quick and fair peer-review system, which is all easy to use. Visit http://www.dovepress.com/testimonials.php to read real quotes from published authors.

Submit your manuscript here: http://www.dovepress.com/clinicoeconomics-and-outcomes-research-journal 